\title{
Goethe Lyrics from a Schubertian Point of View. Analysis of Converse Paths of Creation
}

\author{
OANA ANDREEA SEVERIN \\ "George Enescu" National University of Arts Iași \\ ROMANIA*
}

\begin{abstract}
Throughout the entire evolution of events in the history of music, we are finding the presence of a miniature genre, with a fulminatory evolution in the Romantic period. A syncretic genre, by combining poetry with music, lied generated a highly complex and artistically refined result, hence the preferred leaning of musicians towards it. In the approach of a mythologic page transposed into a Romantic view, in Ganymed we find two figures of genius connected: Goethe - writer and philosopher with a special inclination towards versified creations, with a remarkable, long-lasting activity and with a highly profound view on life - and Schubert - prolific composer, with the most representative contribution in the evolution of this genre, by setting down demarcations and also excelling from a quantitative point of view. This analysis begins from the opposite decoding of the acoustic message, from the point of view of the vocal interpreter, including here most of the implicit aspects: from phonetics to prosody, from dynamics to voice quality in the lied genre, from agogics to breathing and pneumo-phonic accord, from formal organization depending on the construction of the stanza.
\end{abstract}

Keywords: song, poetry, mythology, pneumo-phonic accord, phoneme, Ganymed.

\section{Introduction}

The Lied, cult musical genre, as defined by a joining of the human voice and an instrument, experiences a spectacular ascending becoming, present since the oldest times, until contemporaneity. A symbiotic genre between poetry and music, it started more and more to draw the attention of composers especially by the end of the $18^{\text {th }}$ century, being strongly connected to the emergence of Classicism, through the presence of the creations of W.A. Mozart, L. van Beethoven and the first appearance of Romanticism. If in the beginnings, poetry ${ }^{1}$ was represented by folk creations, subsequently music managed to support elaborate versified literary designs, of a great evocative capacity, with various possibilities of essentializing affects, together with a

\footnotetext{
*oanaandseverin@yahoo.com

${ }^{1}$ Poetry: form of art, literary creation in verses, in which language is used for its aesthetic and evocative qualities, to complete or replace its apparent meaning. (Aristotle was one of the first thinkers who defined poetry in the treaty Poetics). The characteristics of the poetic construction are expressive images, which are asserted by an intensive language, full of sensitiveness.
} 
distinguished dramaturgy profoundness. Thus, the cult singing extended into the musical language sphere the formal characteristics of poetry, referring here to the structure of versification, the arrangements of accents and their alternation, rhythm and measure in its diversity.

Founder of the genre of the cult song, by establishing its formal coordinates, Franz Schubert (1797-1828) left us a legacy which contains more than 600 genre creations. His creative activity can be placed at the border between late Classicism and the beginning of Romanticism. Highly attracted to the lyric genre, the composer managed to capture some of the most sensitive and subtle meanings of the creations of various poets, such as: Johann Mayrhofer and Friedrich Schiller, then Heinrich Heine, Friedrich Rückert, Joseph Freiherr von Eichendorff, Ludwig Rellstab, Johann Gabriel Seidl and, last but not least, Wilhelm Müller for whose verses he composed the famous cycles Die schöne Müllerin and Winterreise.

One of the outstanding literary figures, who profoundly and creatively impressed him, was Johann Wolfgang von Goethe (1749-1832), German humanistic poet, illustrious thinker and a scientist. With a fine education, son of an eminent state clerk, he represents one of the most notable models of individuality of the universal culture.

In his vast literary will, the versified creation was preferred, representing a constant and, thus, "the mirror of his entire personality, his entire mindset" (Goethe, 1999, p. XXIII) ${ }^{2}$. The essential characteristic of the writer's poetic creation is constituted by a profound lyricism, permanently accompanied by a subtle dramatic character. Even "Goethe's drama creations, in their turn, are all bathed in a high lyricism atmosphere" (Goethe, 1999, p. XXIII). The poet's philosophic standpoint is also manifested as a constant, in which human values and especially man, as an individual entity, have the precedence.

The ideas and creations of the great literary man determined Schubert to use around 71 of his poems, giving rise to certain highly profound and valuable musical miniatures. Unfortunately, Goethe did not listen to the Schubertian musical variants, while he was alive. Only after the composer's death did he discover and appreciate his masterpieces (François-Sappey \& Cantgrel, 1994, p. 627).

\section{Analysis of Converse Paths of Creation}

Lied Ganymed, op. 19, no. 3, D 544, was composed by Franz Schubert in 1817 , at the age of twenty. The literary base for this creation is found in the volume entitled Prometheus, which constitutes the second volume of poetries

\footnotetext{
${ }^{2}$ Goethe wrote verses since he was 7 years old until 83 .
} 
of Goethe, published in 1785. The subject is represented by the mythical young Ganymed $^{3}$, in a profound divine bliss before the beauty of spring ${ }^{4}$. In fact, here, as Ion Pillat asserts (Goethe, 1999, p. XXX) "we live lyrically the poet's liberation, carried away in the clouds, in the bosom of the Father in whom he loses himself'. This poem, Ganymed, is closely followed by Prometheus, the contrasting pair, the two poems - regarded as a whole - reflecting on the feeling of divine love. Thus, Prometheus represents the creative and rebellious spirit, who, rejected, blatantly confronted the divine essence, and Ganymed, the adored young man, subdued by divinity. In these "short poems of a density of extraordinary pathos, of a power of sentimental explosion of each word" (Goethe, 1999, p. XXX) Goethe presents both identities as aspects or forms of the human condition, exposing his own philosophy.

Ganymed is a lyric poem by excellence, without any dramatic accents, a fact also observed in the evolution of the acoustic discourse, the dynamic range being restricted to sonorities without sforzando, only the plenitude of an $f f$. It does not have the complexity of a lied as Erlkönig, which would constitute the opposite pole, by the proposed dramaturgy and dramatism. Designed in the F major key, it is one of the most known and loved Schubertian Romantic miniatures, considered one of the genre masterpieces.

Starting from the free structure of the Goethe's poem, the composer thus subscribes the form construction. The tonality design presents three important inflexions, which are also reflected in the stimulus of the acoustic discourse: with a debut in $A$ b major, continues as such until the next tonal center, in $C b$ major (m. 31). The establishment on a new gravitational center then emerges, (m. 46), where the new mode, $G b$ major, goes through an enharmonic reinterpretation $(g b=f \#)$ : $E$ major. After a short section with various modulations (m. 75), only the key signature of $F$ major will be modified, after which (m. 79), it shall be settled as a new tonal center, which remain consistent until the ending (m. 121).

The first section (mm. 1-31) begins with a piano introduction (mm. 1-8), which distinguishes itself using a new formula of punctuated rhythm and discontinuous accompaniment to the bass line, in staccato. It proposes a symmetrical motive construction, in a cumulative progress, culminating on the first beat in the $6^{\text {th }}$ measure, so that it then shall have a closed beat in the $7^{\text {th }}$

\footnotetext{
${ }^{3}$ Goethe's poetry evokes the moment when Ganymed, a demigod from the Greek mythology, son of Trojan king Tros and of Dardania, was kidnapped by Zeus, who took the face of an eagle, and was taken to Olympus to be the cupbearer of Olympian gods, replacing Hebe. $\mathrm{He}$ thus becomes immortal. He was described by Homer as being "the most beautiful amongst mortals." In Roman mythology, Jupiter owned the same role as the one of Zeus in the Greek pantheon.

4 "Since 1785, Goethe has been enthralled by botany [...] he recognized God in everything, as a necessity and law." (Martini, 1972, p. 217).
} 
measure. The punctuated rhythm stimulates the acoustic discourse, for a reflection as close as possible to the literary meaning (the plenitude of joy, of feeling), a highly creative state and for the vocal performer.

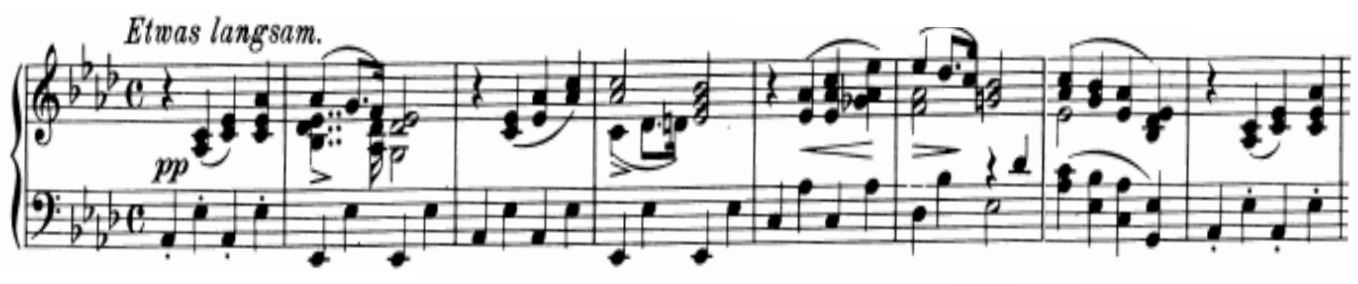

Fig. 1 Franz Schubert, Ganymed, mm. 1-8

The emergence of the voice (m. 9) brings back the previous sentence for the piano, the vocal melodic line being cursive, in legato, with high rhythmic values, contrasting with the accompaniment.

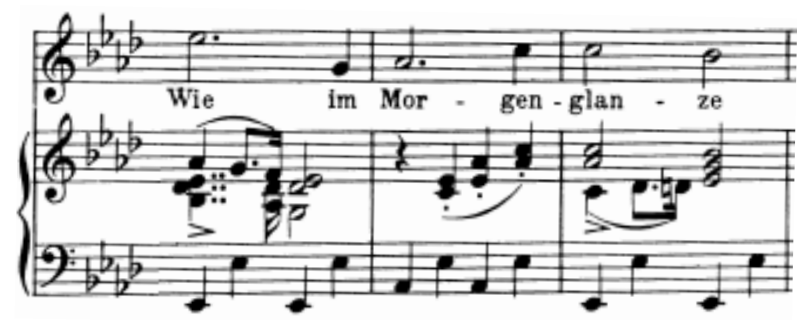

Fig. 2 Franz Schubert, Ganymed, mm. 9-11

The three phrases are congealed into a large breathing period, in compliance with the descriptive, emphatic text: Wie im Morgenglanze/ Du rings mich anglühst,/ Frühling, Geliebter! (As in the morning brightness/ The flame wraps me, Spring, beloved! $)^{5}$. The melodic discourse presents large leaps of a minor sixth $(6 \mathrm{~m})$, which helps in emphasizing the words, with the help of accented metric syllables (Fig. 2). These require an increased attention in the technical execution, for maintaining a sustained legato, without uncontrolled accents. The same attention shall be also exercised for the onsets, at the beginning of the words and sentences, clearly, gently executed, without any acoustic "parasites"6. These aspects

\footnotetext{
${ }^{5}$ Our translation.

${ }^{6}$ On a careful acoustic analysis, the impossibility of their perception from a high distance is noticed (the experience signals the impossibility of the perception further than the placing of the first row of chairs of an auditorium). Instead, we insist for this purpose, on the accentuation towards exaggeration even of the entire complex of interpretative intentions.
} 
can be successfully executed both as a result of a correct pneumo-phonic $\operatorname{accord}^{7}$, as well as the careful pronunciation of the consonants in the beginning.

In the third sentence of the first period (mm. 16-18) two of the words that the composer chose to be defining in the structure of the poem are emphasized, namely Frühling (Spring) and Geliebter (Beloved). Schubert chooses, in this case, to execute their marking on three coordinates: the melodic construction is the first one, with the help of the differentiation on the register levels, the prosodic accents being placed on notes in the medium-acute register ${ }^{8}$, followed by a descending leap, which emphasizes them. Then the placement on down beats (respectively on the third one in the $4 / 4$ measure) shall also help for his purpose. And last but not least by duration, respectively the punctuated value. The intentions previously discerned also reflect in the piano dynamics, by the accents marked in stride, in symmetry.

From an interpretative point of view, the accomplishment of the abovementioned entails the color differentiated approach of the words and the dynamic support of the melodic contour of the sentences.

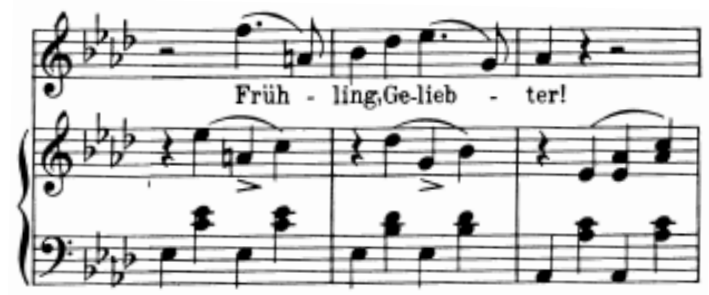

Fig. 3 Franz Schubert, Ganymed, mm. 16-18

The successive period ( $\mathrm{mm}$. 18-31) dynamizes the left-hand accompaniment, by the presence of the eight notes, superposed on a construction similar to the line seen in the bass in the first period (in staccato quarter notes). The vocal melody is differentiated by a stepwise progress, culminating with the highest sound present in the construction of the sentence. For this purpose, the debut of the sentence shall dynamically subscribe, with a

Thus, as the potential uncontrolled sonorities disappear up to the first rows of the audience, similarly a bland interpretation cannot be enforced.

${ }^{7}$ The correct functioning of the phonic apparatus requires a balance that Jean Tarneaud (1888-1972), ENT physician, defined as a pneumo-phonic accord. This constitutes one of the basic elements of correct speech. It refers to the synchronization between breathing and the phonation itself (Ormezzano, 2000, p. 153).

${ }^{8}$ The sounds in the medium-acute register are easily distinguished, due to high frequencies, and the implicit dynamics. 
small shade, of piano. A careful measuring of the air quantity shall sustain the emphasis of the accentuated won syllable, part of the composite word Liebeswonne (precious delights).



Fig. 4 Franz Schubert, Ganymed, mm. 19-21

The first section shall complete in an emphatic and conclusive manner, Unendliche Schöne! (Unending beauty!) (mm. 28-31), with a harmonic evolution which beats in the $C b$ major key, a moment which technically entails great attention, both regarding the measuring of the air quantity and from a dynamic point of view. Several clarifications are necessary here: a sustain in the forte shade throughout four beats can seem static, an assertion applicable to both partners. Thus, following the tensional determination of the piano $^{9}$, it can decrease after the first beat of the $28^{\text {th }}$ measure so that the launch in crescendo which follows shall be executed elegantly, without acceding to hard, extreme sonorities.

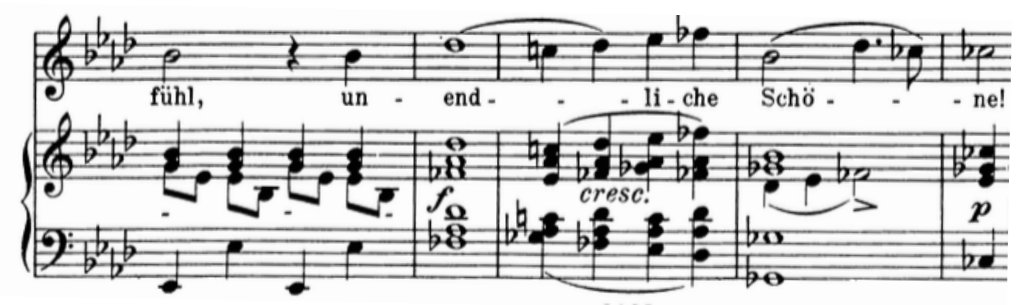

Fig. 5 Franz Schubert, Ganymed, mm. 27-31

In the next section (mm. 31-46), the piano upper line will be modified and is stimulated by the presence of triplets, maintained the rhythm punctuated in the superior level and inserting at the inferior one the metric and rhythmic formula of the syncope to support the meaning of the other melodies. This section proposes a voice melody fragmented alternatively, with the same

${ }^{9}$ Even with a support pedal, due to physical and acoustic reasons, the sonority of the piano cannot be maintained equal throughout the 4 beats, the sound losing from the high shade. 
purpose of avoiding static moments and emphasizing, as opposed to, important suggestive words (which can produce changes in the emotional state). Amongst these there are: Arm (arm), Busen (chest), schmachte (yearn).
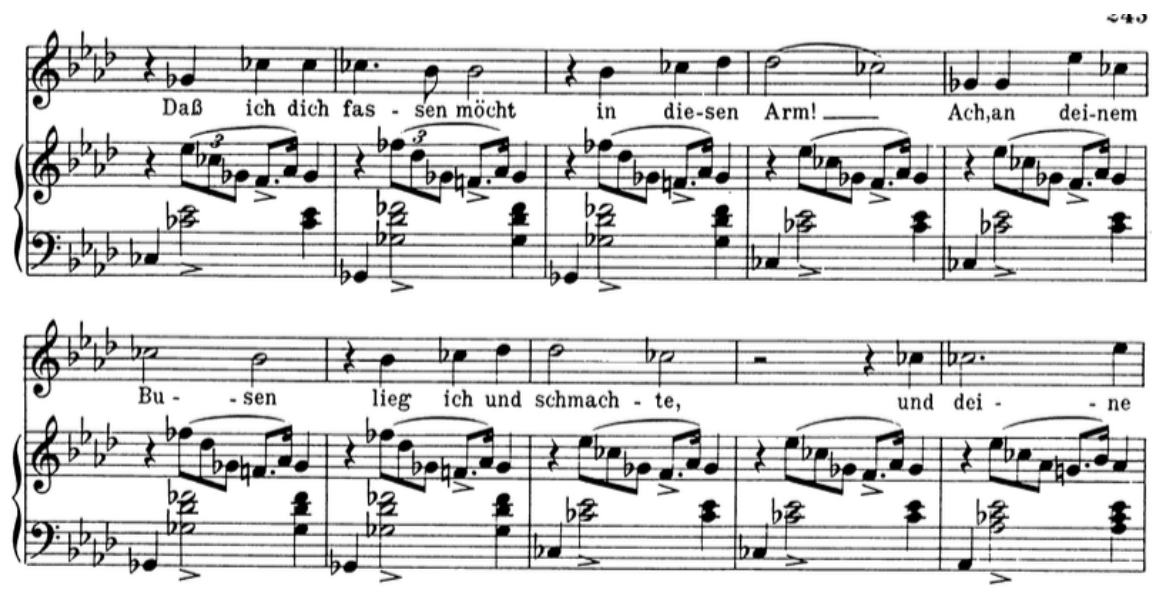

Fig. 6 Franz Schubert, Ganymed, mm. 32-41

All these words require a color differentiation, in support of the emotional meanings suggested by the harmonic movement, differentiations which can be executed with the aid of the extension of the consonants in line with the prosodic accents. For this purpose, we also use the construction of the consonant phonemes, such as the one at the beginning of the word Blumen (flower), of a great expression due to the juxtaposition of consonant phonemes $b$ and $l$. By the extension of the important consonants the possibility of the delimitation of the emotional burden specific to each word is created, but also the rapid change in the emotional state, by the individual expressiveness.

The conclusion of the period (mm. 43-46) is marked by the beat in the $G$ $b$ major mode (subsequently viewed as enharmonic, in the execution of modulation E major - m. 56), through a sentence of large breathing: Und deine Blumen, dein Gras, Drängen sich an mein Herz (Thy flowers and herbs/ On my chest gather).

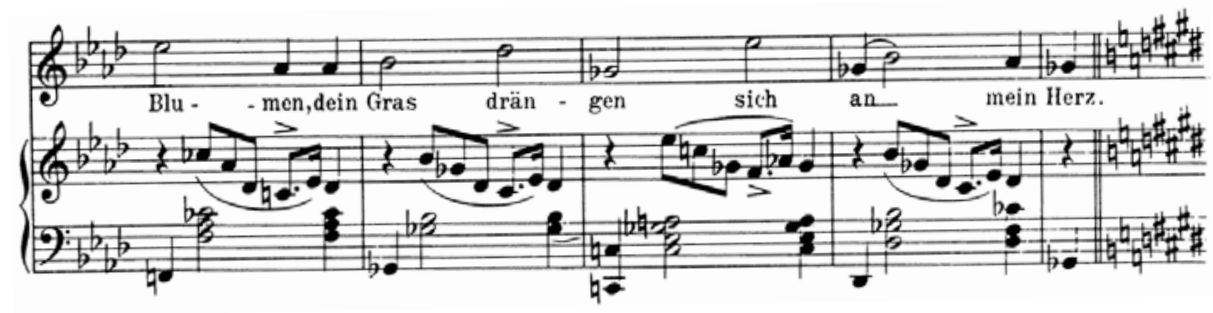

Fig. 7 Franz Schubert, Ganymed, mm. 42-46 
The subsequent period $(\mathrm{mm} .46-56)$ represents a transition and inflects in an enharmonic manner $(g b=f \#, \mathrm{~m}$. 46) towards $E$ major, the varied accompaniment taking over the previous melody, with an interlude of 4 solo piano measures, which continue in the sense of emotional comforting, then the fragmented evolution of the voice comes back, through arpeggio leaps.

One of the characteristics of the Schubertian perspective ${ }^{10}$ is the concept of offering both partners the possibility of creating emotional states, in close interdependency. A continuous melodic flow between the piano and the voice, which determine each other ${ }^{11}$, generating present, evocative emotions, highly suggestive images. Thus, the self-evident intervention of the voice, through which the motive of the piano trill is introduced (m. 56), is highly suggestive for the maintenance of the poetic meaning: the singing of the nightingale (ruft drein die Nachtigall) ${ }^{12}$, but also of the morning wind (Morgenwind). In the context, this also generates a sudden change of affect.

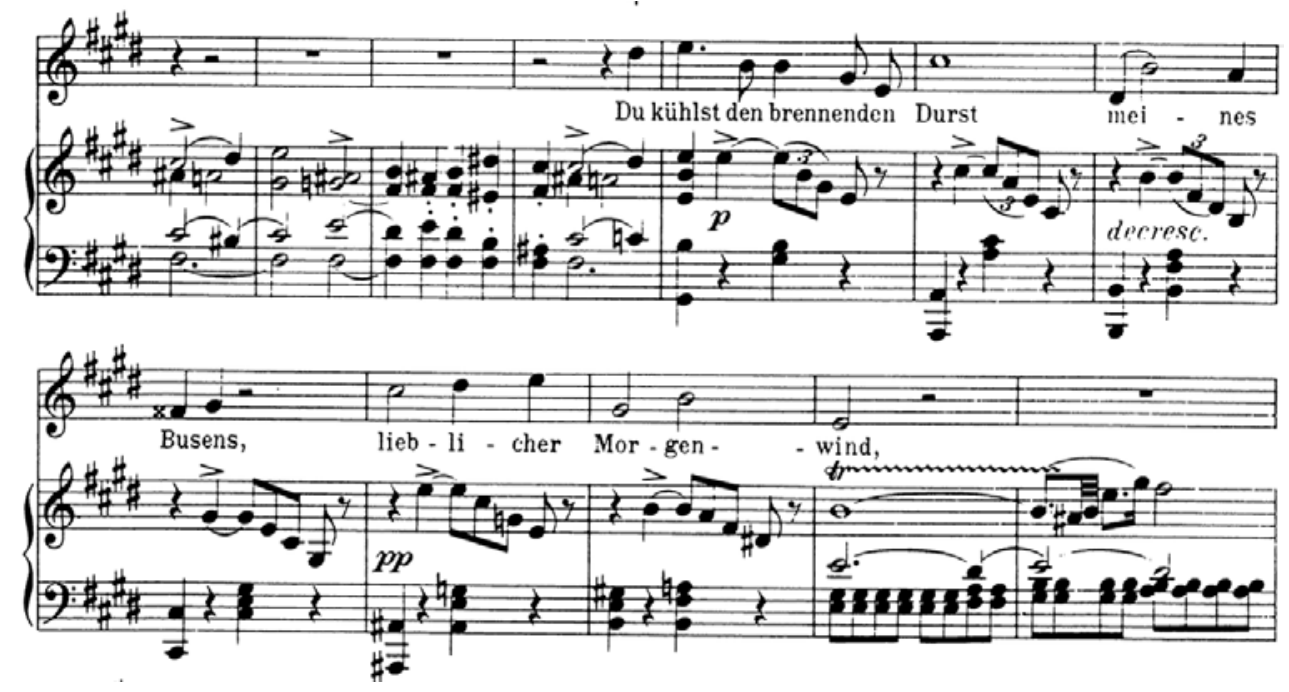

Fig. 8 Franz Schubert, Ganymed, mm. 46-57

\footnotetext{
10 Although not innovative, as the predilection for the investment of the accompanying instrument with meanings and suggestive and expressive images has been observed starting with the previous period. (Only a few conclusive examples: Als Luise die Briefe... de W.A. Mozart, L. van Beethoven, J. Haydn - The Mermayd's song etc.

${ }^{11}$ We support the power of suggestion and the circulation of emotions between partners.

12 The nightingale represents one of the symbols of Romanticism. It has always been a source of inspiration for poets and musicians, due to its extremely beautiful voice, with spontaneous and creative trills. A small-sized bird, with a modest plumage, smaller than a sparrow, was kept in golden cages for its singing full of charm.
} 
The presence (mm. 68-78) of a contrasting section, through short, interrogative-affirmative motives, sustained by the voice, overlapped to the backup modified, stimulated with eights staccato, suggestively express the inner turmoil, joy, the plenitude of feeling with the help of agogic marks, un poco accelerando (m. 68), and of dynamic fluctuations. Therefore, the acoustic discourse shall be tensionally led to the climax in the $71^{\text {st }}$ measure, then it shall sequentially be decreased on the repetition of the word wohin? (where?). All these variations, complementary emotional states must be reflected in an interpretative manner.

The small durations complied with, even shortened, for the imitation of the piano (descrescendo on the unaccented beat, ich komme, m. 70), must not be here mistaken with the piano dynamics, but related to the prosodic accent. In the sequential repetition of the word wohin, resumed in descrescendo (even with an echo), the emotional state requires support, this being achieved by the correct interpretation of the short duration, which shall offer a greater dramatic character. It covers awe, anxiety, fear, due to the kidnapping into the clouds, into another, unknown space.

Starting with the $74^{\text {th }}$ measure the melodic and dynamic ascension shall be resumed, so that on the $78^{\text {th }}$ measure it shall plenary culminate into fortissimo (hinauf - upward), on one of the highest sounds in the compass proposed by the lied.

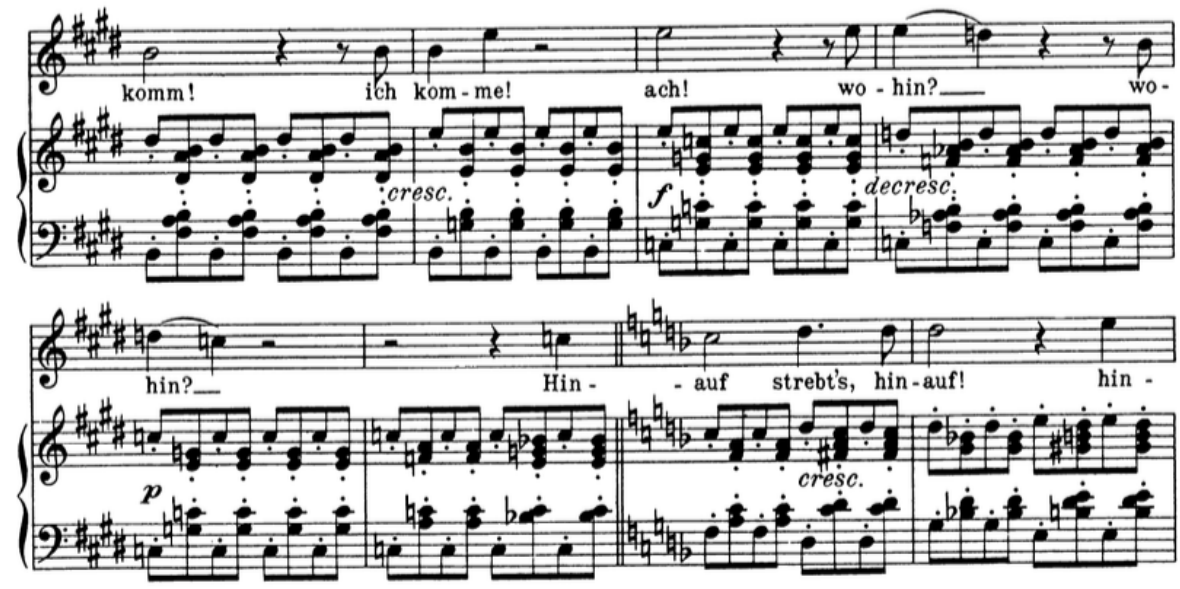

Fig. 9 Franz Schubert, Ganymed, mm. 69-76

The new tonal center, $F$ major, which settles down and will be maintained until the end of the creation, delimits the last section (mm. 79-121). The acoustic material consists of the two-time repetition of the same fragment and of an extension with the role of a Finale, with sudden variations of emotional states. 
Thus, to illustrate, we notice the access into an opposite affect with the help of the sudden movement of the piano accompaniment, executed by the extension of rhythmic durations, but also by changing the interpretative stylistic practices: from staccato to legato.

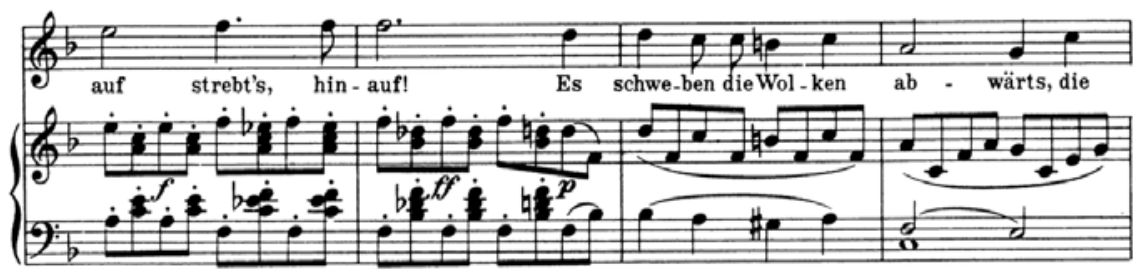

Fig. 10 Franz Schubert, Ganymed, mm. 77-80

Also, for this purpose, after the rhythmic build-up throughout the seven measures (mm. 85-91), the surprise of the climax (m. 92) arises again with the piano aid, by means of the same method: the sudden transition from the backup in the eigth notes, to the one with large durations, half notes and quarter notes. This moderation of the carrying out generates the rapid change of the previous state, an effect anticipated by the composer, preparing the climactic moment of the creation ${ }^{13}$.

Of a great expression, in the context, is the repetition of the word Mir! Mir! (to me! to me!), this offering the vocal interpreter the possibility of a wider dynamical-tensional range ( $\mathrm{mm} .85-86)$.

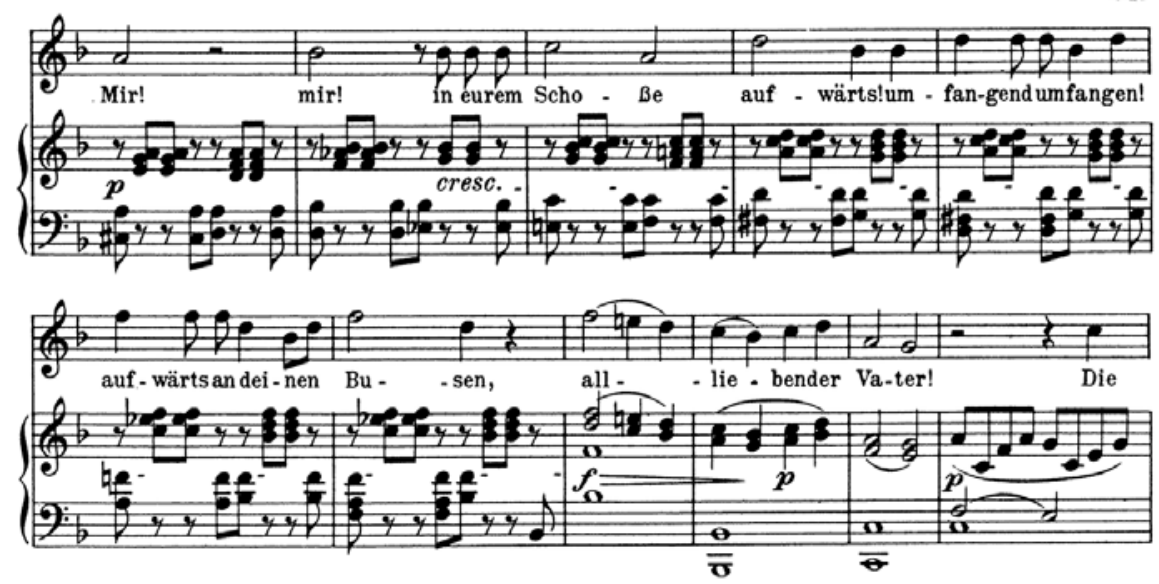

Fig. 11 Franz Schubert, Ganymed, ms. 85-95

13 For the emphasis on the surprise elements, these shall be prepared, depending on the situation: with a crescendo in the case of a subito piano, with an almost imperceptible caesura, in the case of an ff crescendo started as late as possible etc. 
The strategy is repeated, by the re-emergence of the execution of the backup in the eight notes, together with the resuming the last verses. The modification occurs in the $10^{\text {th }}$ measure, by means of the extension with the help of the open cadence with the repetition of other keywords for the structure of the poem: Alliebender Vater! (All-loving Father!). This would also constitute a final difficult moment for the vocal interpreter, by the sustain of the large breathing sentence (mm. 110-161), also including the fatigue accumulated in the previous one, with the same technical issue (mm. 106-110).

Through a tradition of the stylistic and interpretative requirements, the impossibility of sectioning the sentence for physiological purpose is confirmed. The air gradation shall be organized depending on the determination of the meaning of the sentence, on the rise of the melody or its contrary, but also depending on the word, of the language morphology and syntax. Therefore, breathing inside the word is forbidden ${ }^{14}$, operating in the sense of economy, of a careful gradation of the air column.

Moreover, the interpretative tradition also offers us certain solutions, such as: the entrance of the sound (m. 110) in a medium dynamic, the diminished towards minimum ${ }^{15}$, a reduced-size accelerando subscribed to the melodic meaning, as well as the concentration of vowel $a$, through the rounding of the orbicular muscles towards vowel $o$.

Vowel phoneme $a^{16}$ requires a higher air quantity, unlike $o$, the rounded posterior semi-closed vowel, involving a sure differentiation due the anatomical-physiological formation, but also depending on the registers. Thus, to facilitate the gradation of the air column, as well as to sustain a qualitative sonority, it is imperceptible deviated from $a$ towards $o$, from the medium register to the acute one (Fucito \& Beyer, 1922, p. 151).

The end (the last six measures) brings the piano back into the spotlight, with a choral type construction and, thus, constituting a symmetrical conclusion of the creation. Here we can make a reference to the dynamic interdependency of the partners, as the final note of the vocal melody coincides with the debut of the piano sentence. The close relationship between the partners is also determined by the distribution of the melody among them, to be perceived as a whole, not like a separate delimitation. Thus, for a refined interpretation, a voice shall be developed from the dynamics of another.

\footnotetext{
${ }^{14}$ Together with the other rules of breathing placement, depending on the sentence syntax. But, basically, composers solve these problems, by the melodic construction.

15 The reduced dynamics is directly proportional to the necessary amount of the air quantity involved.

${ }^{16}$ Unrounded central open vowel (Corniţă, 2001, p. 61). This is pronounced with the mouth relatively open, and with the tongue away from the palate, being considered the most difficult vowel to achieve for vocal performers (Miller, 1996, p. 155).
} 


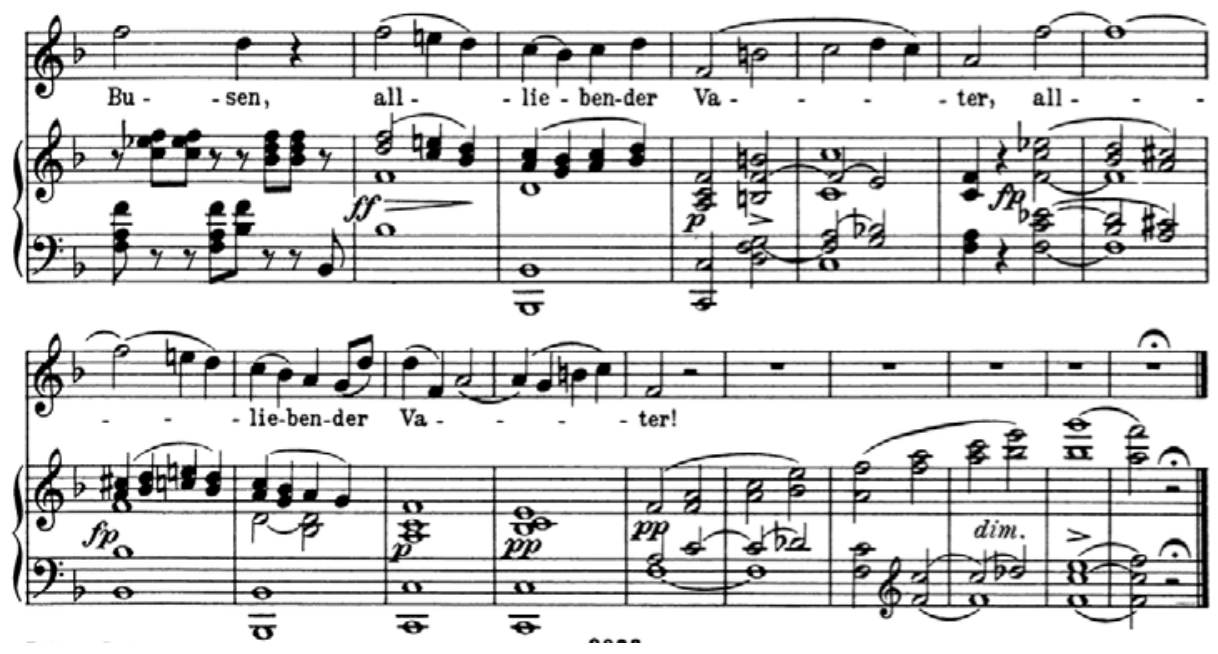

Fig. 12 Franz Schubert, Ganymed, mm. 105-121

The duration of the lied is of approximately $8^{\prime}$, throughout the 121 measures. The melody implies a comfortable tessitura for the voice of a soprano or tenor, with a range between $d \# 1$ and $g 2$. However, amongst the notable technical difficulties, we signal the large breathing sustained sentences, with a melodic contour characterized by frequent leaps, representing a touch of originality for the lyric character of the creation.

The dynamic organization is easily noticed from the writing, respectively from the construction of the melody. The meaning of the poetry, lyric by excellence, without dramatic touches, reflects itself directly in the sphere of dynamic notations. The composer does not mark any indication in the vocal staves. Thus, implicitly, it shall extend and take into consideration the notations present in the piano backup: an extended range, from $p p$ (pianissimo) to $f f$ (fortissimo).

Regarding the minimum and maximum sonorities, individually possible, these are relative and depend on the sum of several factors, such as: the sizes of the auditorium (Creangă, 2014, p. 331), the degree of the reverberation of the acoustic wave in a determined space, of the acoustic modifications occurred in the case of the presence or not of an audience, of the degree of attention of the audience/receptor, etc.

The agogic indication Etwas langsam (a little slower ${ }^{17}$ ) offers a somewhat higher freedom to the interpreters, but it can also be viewed as a being uncertain. However, apart from the same interpretative tradition, we ought to relate to several aspects determinative in the acoustic translation:

17 etwas - something, langsam - slow. 
firstly, the possibility of offering a tensional meaning in line with the message contained, which might be lost, by dilution, in the case of a slower approach, must be considered. Also, for this purpose, another determinative aspect is constituted by the possible physiological breathing of the voice, pre-established by the composer by placing the line of legato and by the phraseological construction.

In particular, it shall determine the agogic size depending on the most difficult sentence in the vocal partition, of great support (mm. 110-113), considering the possibility of dosing the air column, in an evolution in line with the lyric cantilena character of the lied, and the smallest rhythmic gradations present in the construction of the acoustic discourse $(\mathrm{mm} .58-60)$, in order to not be tempted to approach a fast moving.

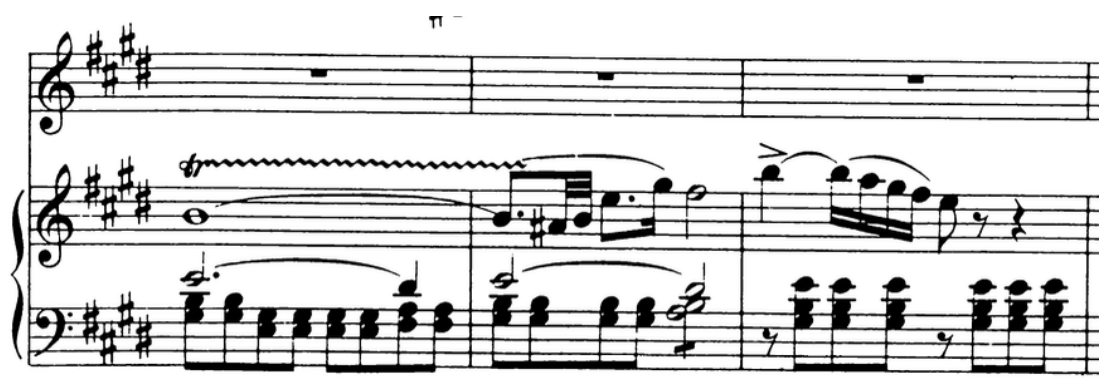

Fig. 13 Franz Schubert, Ganymed, mm. 58-60

\section{Conclusions}

Regarding the importance of complying with the partition and the attention paid to the semiotic translation, we shall not insist on its long-debated aspect, but we must emphasize its great importance. Composers, in the elaborate creation process, do not leave any aspect in the notation to chance, a fact which, certainly becomes clear to subsequence interpreters. In turn, they retake the trajectory opposite to the chronology of the creation process, in the action of decoding and creating acoustic meanings. Thus, it implicitly reached the compulsoriness of complying with the determination of the musical language by the profound meanings of the literary base.

The comprehension of the profound meanings of the acoustic message also reflects on the decoding of the literary language. Thus, in our case, the translation of the text into German is certainly of primordial importance, where it is required that as much as possible from the profound emotional meaning held shall shine through. Certainly, literary translations, which focus on maintaining the same affects, are of use, but we opt for an understanding of each word, particularly, which effectively represents the explanation of the meanings and of the dynamic and agogic graphic signs. 
The acoustic quality of the voice in the lied genre is fundamental in a genre intended for a limited, chamber, intimate space and entails a careful compliance with the phonic accuracy. Firstly, a qualitative acoustic emission must be mentioned here, without uncontrolled air leakage ${ }^{18}$, which can be included in the sphere of acoustic "parasites", together with a balanced acoustic interlacing of the dynamic balance between partners. For this purpose, should not to exaggerate large sonorities, which can be disturbed in a limited space, which ought to sustain the requirements in the sphere of the aesthetics, characteristic for the miniature, lyric genre, with rare extrovert accents ${ }^{19}$.

\begin{tabular}{|c|c|c|}
\hline Original version & Romanian translation & English translation \\
\hline $\begin{array}{l}\text { Wie im Morgenglanze } \\
\text { Du rings mich anglühst, } \\
\text { Frühling, Geliebter! } \\
\text { Mit tausendfacher } \\
\text { Liebeswonne } \\
\text { Sich an mein Herz drängt } \\
\text { Deiner ewigen Wärme } \\
\text { Heilig Gefühl, } \\
\text { Unendliche Schöne! }\end{array}$ & $\begin{array}{l}\text { Ca-n luciul zorilor } \\
\text { Mă-nvălui în văpaie } \\
\text { Primăvară-îndragită! } \\
\text { Scumpă-nmiita desfătare } \\
\text { A căldurii tale pururi } \\
\text { Inima-mi cuprinde, } \\
\text { Sfânt simțământ, } \\
\text { Frumusețe fără margini! }\end{array}$ & $\begin{array}{l}\text { How, in the morning } \\
\text { brightness, } \\
\text { You all around shine at me, } \\
\text { Springtime, Beloved! } \\
\text { With thousandfold love-bliss } \\
\text { The holy feeling } \\
\text { Of your eternal warmth } \\
\text { Presses itself upon my heart, } \\
\text { Unending beauty! }\end{array}$ \\
\hline $\begin{array}{l}\text { Daß ich dich fassen möcht' } \\
\text { In diesen Arm! }\end{array}$ & $\begin{array}{l}\text { De te-aș putea învălui } \\
\text { Cu-aceste brațe! }\end{array}$ & $\begin{array}{l}\text { Could I but embrace you } \\
\text { In this arm! }\end{array}$ \\
\hline $\begin{array}{l}\text { Ach, an deinem Busen } \\
\text { Lieg' ich, schmachte, } \\
\text { Und deine Blumen, dein } \\
\text { Gras } \\
\text { Drängen sich an mein } \\
\text { Herz. } \\
\text { Du kühlst den brennenden } \\
\text { Durst meines Busens, } \\
\text { Lieblicher Morgenwind! } \\
\text { Ruft drein die Nachtigall } \\
\text { Liebend nach mir aus dem } \\
\text { Nebeltal. } \\
\text { Ich komm', ich komme! } \\
\text { Wohin? Ach, wohin? }\end{array}$ & $\begin{array}{l}\text { Ah, la sânul tău } \\
\text { Zac mereu tânjind, } \\
\text { Ale tale flori și ierburi } \\
\text { La piept mi se-adună. } \\
\text { Tu îmi alini arzătoarea } \\
\text { Sete din piept, } \\
\text { Adiere gingașă în zori! } \\
\text { Mă cheamă, mult } \\
\text { iubitoare, } \\
\text { Privighetoarea din negura } \\
\text { văii. } \\
\text { Sosesc, iată, sosesc! } \\
\text { Încotro? Ah, încotro? }\end{array}$ & $\begin{array}{l}\text { Ah, upon your breast } \\
\text { I lie, languish, } \\
\text { And your blossoms, your } \\
\text { grass } \\
\text { press upon my heart. } \\
\text { You cool the burning } \\
\text { Thirst of my bosom, } \\
\text { Lovely morning-wind! } \\
\text { There calls the nightingale } \\
\text { Lovingly for me from the } \\
\text { misty vale. } \\
\text { I come, I come! } \\
\text { Whither, ah whither? }\end{array}$ \\
\hline
\end{tabular}

${ }^{18}$ Here we refer to the clarity of the onset (Miller, 1996, p. 4), especially at the beginning of the sentence, but also at the end of it.

19 The aspect of the decrease in the vibrations of vocal cords, in the situation of a dynamic exaggeration, with sure reverberations in the timbre aspect. 


\begin{tabular}{|l|l|l|}
\hline Hinauf! Hinauf strebt's. & Spre bolți! Spre bolți & Up! Up it surges. \\
Es schweben die Wolken & râvnind! & The clouds are leaning \\
Abwärts, die Wolken & Flutură norii & Downwards, the clouds \\
Neigen sich der sehnenden & Tot mai jos, norii & Bow down to yearning love. \\
Liebe. & Tind spre al dragostei dor. & To me! To me! \\
Mir! Mir! & Mie! Dar mie! & In your lap, clouds, \\
In eurem Schosse & Într-al vostru sân & Upwards! \\
Aufwärts! & Spre bolți! & Embracing, embraced! \\
Umfangend umfangen! & Cuprins, să curpind! & Upwards to thy bosom, \\
Aufwärts an deinen Busen, & Spre bolți la pieptul tău, & All-loving Father! (9) \\
Alliebender Vater! & Părinte atotiubitor! & \\
\hline & & \\
\hline & (N. Argintescu-Amza) & \\
\hline
\end{tabular}

\begin{tabular}{|c|c|}
\hline $\begin{array}{l}\text { Ganymede } \\
\text { English Translation (C Richard Wigmore }\end{array}$ & \\
\hline $\begin{array}{l}\text { How your glow envelops me } \\
\text { in the morning radiance, } \\
\text { spring, my beloved! } \\
\text { With love's thousandfold joy } \\
\text { the hallowed sensation } \\
\text { of your eternal warmth } \\
\text { floods my heart, } \\
\text { infinite beauty! }\end{array}$ & $\begin{array}{l}\text { How in the morning light } \\
\text { you glow around me, } \\
\text { beloved Spring! } \\
\text { With love's thousand-fold bliss, } \\
\text { to my heart presses } \\
\text { the eternal warmth } \\
\text { of sacred feelings } \\
\text { and endless beauty! }\end{array}$ \\
\hline $\begin{array}{l}\text { O that I might clasp you } \\
\text { in my arms! }\end{array}$ & $\begin{array}{l}\text { Would that I could clasp } \\
\text { you in these arms! }\end{array}$ \\
\hline $\begin{array}{l}\text { Ah, on your breast } \\
\text { I lie languishing, } \\
\text { and your flowers, your grass } \\
\text { press close to my heart. } \\
\text { You cool the burning } \\
\text { thirst within my breast, } \\
\text { sweet morning breeze, } \\
\text { as the nightingale calls } \\
\text { tenderly to me from the misty valley. } \\
\text { I come, I come! } \\
\text { But whither? Ah, whither? }\end{array}$ & $\begin{array}{l}\text { Ah, at your breast } \\
\text { I lie and languish, } \\
\text { and your flowers and your grass } \\
\text { press themselves to my heart. } \\
\text { You cool the burning } \\
\text { thirst of my breast, } \\
\text { lovely morning wind! } \\
\text { The nightingale calls } \\
\text { lovingly to me from the misty vale. } \\
\text { I am coming, I am coming! } \\
\text { but whither? To where? }\end{array}$ \\
\hline $\begin{array}{l}\text { Upwards! Strive upwards! } \\
\text { The clouds drift } \\
\text { down, yielding } \\
\text { to yearning love, } \\
\text { to me, to me! } \\
\text { In your lap, } \\
\text { upwards, } \\
\text { embracing and embraced! } \\
\text { Upwards to your bosom, } \\
\text { all-loving Father! }\end{array}$ & $\begin{array}{l}\text { Upwards I strive, upwards! } \\
\text { The clouds float } \\
\text { downwards, the clouds } \\
\text { bow down to yearning love. } \\
\text { To me! To me! } \\
\text { In your lap } \\
\text { upwards! } \\
\text { Embracing, embraced! } \\
\text { Upwards to your bosom, } \\
\text { All-loving Father! (7) }\end{array}$ \\
\hline
\end{tabular}


Translations by Richard Wigmore first

published by Gollancz and reprinted in the

Hyperion Schubert Song Edition (8)

\section{References}

Corniţă, G. (2001). Fonetica integrate, ediţia a II-a [Integrated Phonetics, $2^{\text {nd }}$ edition]. Baia Mare: Editura Umbria.

Creangă, S. (2014). Cântul și vorbirea de performanță [Chant and performance speech]. București: Editura Universitară.

Firca, Gh. (Ed.) (2008). Dicționar de termeni muzicali, ediția a II-a [Dictionary of Musical Terms, $2^{\text {nd }}$ edition]. București: Editura Enciclopedică.

François-Sappey, B. \& Cantagrel, G. (Ed.) (1994). Guide de la mélodie et du lied. Paris: Fayard.

Fucito, S. \& Beyer, B. (1922). Caruso and the art of singing. New York: Frederick A. Stokes Company Publishers.

Goethe, J.W. (1999). Poezii lirice. Ediție bilingvă româno-germană, cuvânt înainte de Ion Pillat [Lyrical Poetry, German-Romanian bilingual edition, foreword by Ion Pillat]. București: Editura Graiandi Grai și Suflet - Cultura națională.

Goethe (1974). Poezii. Antologie, cuvânt înainte și note de Ion Acsan [Poems]. Anthology, foreword and notes by Ion Acsan. București: Editura Univers.

Martini, Fr. (1972). Istoria literaturii germane [History of German Literature]. București: Editura Univers.

Miller, R. (1996). The structure of singing. System and art in vocal technique. USA: Schirmer, Cengage Learning.

Ormezzano, Y. (2000). Le guide de la voix. Paris: Éditions Odile Jacob.

Sadie, S. \& Tyrrell, J. (2001). The New Grove Dictionary of Music and Musicians, $2^{\text {nd }}$ edition. London: Macmillan Publishers Limited.

http://www.lieder.net/lieder/get_text.html?TextId $=6413$

https://www.oxfordlieder.co.uk/song/1405

https://en.wikipedia.org/wiki/Ganymed_(Goethe) 